\title{
Articles
}

\section{Encouraging Critical Collaborative Autonomy}

\author{
Tim Murphey \\ Nanzan University
}

\section{George M. Jacobs \\ SEAMEO Regional Language Centre}

In this theory-building review essay, we advocate that second language teachers encourage their students to act critically, cooperatively, and autonomously. We discuss the three components of critical collaborative autonomy, explain why these components fit together, and present ideas for promoting their interaction and development. Being autonomous does not necessarily mean learning in isolation, but rather having the ability to metacognitively and critically make decisions as to the means one uses to learn and develop. It is our contention that students learn autonomy more quickly through guided cooperative learning in which they collaborate with peers to find and create their autonomous and critical voices. The incremental assuming of control of one's language learning within a community not only accelerates acquisition but changes group and individual personalities. While we focus principally on this process in second language acquisition, we also briefly address the wider sociocultural, political, and philosophical nature of such effort.

本榙ては、外国語教師は、学皙者を批判的、協力的、自主的に活動するように励ますい きであると提唱する。“批判的、協力的、自主的な学習集団”の三つの撕成要因を检就 し、なぜそれらが整合性があるのかを明らかにする。さらにに、それぞれの要因がどのよう に影筫し合い、発展していくのがにひて述へる。自主的な学習者であるということは、 必すしも一人で学習するということでは交く、むしろ、各自が学か手段について、客䚌 的、批判的に意志決定する能力を有することを意味している。したがって、教師が好力的 な学習環境を与文ることにより、学習者は、仲間と共に協力し合い、批判的な意見を交わ しながら、より早く自主性を身につける。自主的な学習者は、こうした学習理境の中て、、 言語習得を加速させるばがりではなく、自らを発達させ、学習集团そのものの性格をも変 之ていく。第二可語習得理論のみならす、社会文化的、政治的、哲学的な側面にも言及す b. 
W hen we look back at the past century, we see many ways in which people have gained greater control over decisions that affect their lives. In 1900 many countries were still colonies, most people did not go to school, and many people had little or no access to outside sources of information. In 2000 we see a host of new countries, schooling has become the norm, and technology offers access to a wide range of information with fewer restrictions. Today we see an expanding picture in which many people have more and better ways of understanding and affecting the course of their lives. With specific reference to the situation in second language (L2) education, we see changes that augur well for more control by those who had little formal power before.

One of these changes in L2 education is a growing focus on promoting learner autonomy. In this article we explain how students can become more autonomous, defined here as being aware of and in charge of their choices, by working together In particular we discuss cooperative learning and the stages leading to critical collaborative autonomy. We begin by examining learner-centeredness, a key rationale for learner autonomy.

\section{Learner-Centeredness}

Cognitive psychologists investigating the learning process emphasize the role of learners rather than teachers and materials (Slavin, 1995). This emphasis has inspired a number of changes of focus in education, such as a stress on process over product (Bereiter \& Scardamalia, 1987), and on students as active constructors of knowledge rather than as empty vessels to be filled (Brown, Collins \& Duguid, 1990; Bruner, 1966). Teachers working from learner-centered cognitivist perspectives attempt to facilitate their students' learning because they know they cannot control it, Palmer (1998, p. 6) puts it thusly in reference to university education:

I have no question that students who learn, not professors who perform, is what teaching is all about. . Teachers possess the power to create conditions that can help students learn a great deal-or keep them from learning much at all, Teaching is the intentional act of creating those conditions.

Teachers wishing to create those conditions need learner feedback because students not only construct their own knowledge, but they are also co-constructors with teachers of the environment in which their learning takes place, Furthermore students have many opportunities to construct learning outside the classroom, either on their own initiative or with their teachers' guidance. 
A prominent manifestation of this paradigm shift towards learnercenteredness in L2 education has been the concept of learner autonomy. Dickinson (1999, p. 2), discussing the application of the idea to L2 settings, defines learner autonomy as "an attitude to learning that the learner develops in which the learner is willing and able to make the significant decisions about her learning," Many books and articles on L2 instruction advocate learner autonomy and describe how it can be implemented. However, as we will note, much of the literature on L2 learner autonomy describes students working collaboratively. The next two sections of this article discuss the benefits of collaboration and concepts underlying its facilitation. Afterwards we return to the issue of learner autonomy and discuss the link between collaboration and autonomy.

\section{Why Collaborative?}

Collaboration offers benefits in many areas of life, from sports to the workplace to the family (Johnson \& Johnson, 1994; Kohn, 1992). Collaboration with peers can be especially beneficial. Hartup (1992) maintains that peer relations are important to the social and intellectual development of children as well as to success in adulthood. The world of work, where teams are becoming a more common organizational form and advances in computers have greatly facilitated collaboration, provides further evidence supporting the efficacy of collaboration (Collis \& Heeren, 1993; Hilt, 1992).

Peer collaboration in education can be very powerful. A large body of research suggests that collaboration among students can lead to superior results for a wide range of performance variables including achievement, thinking skills, interethnic relations, liking for school, and self-esteem (for reviews, see Bossert, 1988-1989; Cohen, 1994; Johnson \& Johnson, 1989; Sharan, 1980; Slavin, 1995).

Social learning theory (Bandura, 1977, 1986) describes how we learn from one another through imitation and vicarious experience. However, not all role models in our environment have equal influence. It is suggested that who are close to us in terms of proximity, time, ethnicity, age, sex, interests, and learning have a significant impact upon us as near peer role models (Murphey, 1998a). In the case of L2 education students can easily identify with one another, whereas teachers are more distant role models and thus may not be as effective as near peers who demonstrate ability in the L2. Collaborating students may often learn a great deal from one another simply because they are appropriate role models, providing comprehensible input and learnable information within each others' zones of proximal development (ZPD) 
(Vygotsky, 1978). The ZPD contains learning and tasks that are possible with the help of others but which one person alone is not quite able to achieve.

\section{Key Concepts in Cooperative Learning}

Cooperative learning (CL) can be defined as a set of concepts and strategies for enhancing student-student collaboration. (See Appendix 1 for a list of websites and a listserv on CL, and Liang, Mohan, \& Early, 1998 for a review of some of the L2 literature on CL.) Two concepts central to CL are positive interdependence and individual accountability (Johnson \& Johnson, 1994). Positive interdependence is the feeling among group members that they sink or swim together. If one fails, then all suffer in some way. If one succeeds, then everyone benefits. Group members realize that each member's efforts benefit not only themselves but all other group members as well. Positive interdependence provides a feeling of support within the group not unlike that of a cohesive sports team. This may be compared to the strong cultural tradition in Japan of amae, a kind of dependency that is highly valued.

Individual accountability exists when each member feels responsible to learn, to demonstrate this learning, and to contribute to the learning of group-mates. However, the purpose of CL is for group members to become stronger individuals in their own right. Therefore groups do not measure their success by a particular group product (e.g., a group composition), but by the individual progress of each group member (e.g., the ability of each member to write well and to give useful feedback on the writing of others). Individual accountability provides a feeling of pressure within the group which, hopefully, mixes well with the feeling of support offered by positive interdependence. This combination of peer support and peer pressure is one of the means by which CL attempts to avoid replacing domination by the teacher with domination by the group or by a dominant group member.

Jigsaw (Aronson, Blaney, Stephan, Sikes, \& Snapp, 1978), a CL technique known to many $\mathrm{L} 2$ teachers, provides an example of how student interaction can be structured to promote positive interdependence and individual accountability, Please note the use of the term "promoting" instead of "requiring," "furnishing," "guaranteeing," or "providing" since, in a learner-centered view, all that teachers can do is to promote and encourage. In Jigsaw, each group member obtains unique information to share with the other group members so that the group can perform a subsequent task. Thus, learners are encouraged to support each other by teaching their unique information to the rest of the group. 
At the same time they may feel pressure to learn their information well because the group is depending on them.

Another key concept from the CL literature involves the importance of collaborative skills (Johnson \& Johnson, 1994). For student-student collaboration to succeed, a set of collaborative skills is needed such as disagreeing politely, checking if others understand, and listening attentively, For instance, in research on peer feedback in L2 writing instruction we can see an attempt to help students master the collaborative skills needed to work with one another, e.g., providing feedback checklists and teaching how to give constructive criticism. These collaborative skills are suggested to promote $\mathrm{L} 2$ acquisition by enhancing interaction (Bejarano, Levine, Olshtain \& Steiner, 1997). Furthermore the language needed to operationalize the skills fits well with functional approaches to L2 instruction (Coelho, 1992).

This article began with a discussion of the notion of learnercenteredness, including learner autonomy. The value of student-student collaboration was then explored along with concepts from the literature on $\mathrm{CL}$ which have been suggested to help students work together more eagerly and effectively. Next, we suggest why collaboration aids learner autonomy and, indeed, serves as a vital element in the repertoire of autonomous L2 learners.

\section{Interpreting Learner Autonomy Collaboratively}

As a result of the paradigm shift towards learner-centered education by many $L 2$ educators, students have more of a role in determining what, when, and how they study and how their learning will be assessed. However, with this power comes the responsibility for planning and carrying out learning. Students may shy away from this responsibility and may even resent teachers who try to give up some of their power, labeling such teachers as irresponsible. Here cultural and institutional contexts play important roles (Pierson, 1996).

However, learners who are initially not inclined toward autonomy can be encouraged to be more autonomous. Dickinson (1999) states that $\mathrm{L} 2$ students need both psychological preparation to accept autonomy and methodological preparation to take on the responsibilities that autonomy brings. Methodological preparation involves acquiring strategies and collaborative skills for taking part in planning, directing, and assessing their own learning (Areglado, Bradley \& Lane, 1996). Knowles (1975, cited in Higgs, 1988, p. 44) suggests that competent self-directed language learning includes "[t]he ability to relate to peers collaboratively, to see them as resources." 
Although terms such as learner independence and autonomy may mistakenly be interpreted as solitary learning, the term autonomy does not imply that students study alone (Benson, 1997; Dam, 1995; Harris \& Noyau, 1990; Kenny, 1993; Lee, 1998; Littlewood, 1996; Macaro, 1997; Murphey, 1998b; Pemberton, 1996; Van Lier, 1996). Indeed, Assinder (1991) reports that participating in group activities increased her L2 students' autonomy as well as their accuracy, motivation, participation, and confidence. In Geary's (1998, p. 1) words, students can go "from dependence toward independence via interdependence." Here we emphasize that interdependence and collaboration are not left behind in achieving independence; rather, independence includes learner understanding of how and when collaboration may be beneficial and the right to choose it. In a book on L2 teaching methodology Harmer (1998) suggests:

[Group activities] give students chances for greater independence. Because they are working together without the teacher controlling every move, they make some of their own learning decisions, they decide what language to use to complete a certain task, and they can work without the pressure of the whole class listening to what they are doing. Decisions are cooperatively arrived at, responsibilities are shared (p. 21),

Vygotskian (1978) sociocultural theory lends further support to the idea of collaborative autonomy with its clarifying description of how learning is first "intermentally" constructed between two or more minds and only later appropriated and used intramentally as one's own tool to create more learning (Wells, 1999). In learning there is an ongoing dance between intermental and intramental functioning as we continually construct individual understanding from the discourse of others and combine this understanding with previous learning within our zones of proximal development. It is collaborative interaction that allows partners to adjust to each other appropriately and to give each other what is "learnable" at their respective stages of development. For example, many scholars have advocated the Vygotskian-inspired scaffolded use of peer feedback in L2 writing instruction (e.g., Brown, 1994; Lockhart \& Ng, 1995; Nelson, 1995; Reid, 1993; Stanley, 1992), and Donato (1994) has illustrated how this scaffolding occurs in other types of $\mathrm{L} 2$ tasks as well.

Palmer (1998, p. 74) describes how effective classrooms resolve the apparent paradox between the individual and the group, saying that "space should support solitude and surround it with the resources of community." Rather than being two opposing forces, collaboration and autonomy work together in the same way that CL's "positive interdependence" and "individual accountability" support each other. Palmer 
encourages us to go to a higher level of thinking through the realization that the individual and the community make each other possible; thus we must learn to work harmoniously for the good of both.

\section{Facilitating Collaborative Learner Autonomy}

Murphey (1998b) conceptualizes a process of five stages, or "movements," through which many L2 students seem to pass as they become more autonomous. He also describes activities that can facilitate progress. The five overlapping and often co-occurring movements are: (1) socialization; (2) dawning metacognition; (3) initiating choice; (4) expanding autonomy; and (5) critical collaborative autonomy (see Breen \& Mann, 1997 and Nunan, 1997 for other stage-like descriptions). The first three movements-socialization, dawning metacognition, and initiating choice - can be encouraged from the start of a class by the way teachers structure their teaching. Obviously, participation is greatly determined by the invitational structure that teachers provide and the overall classroom climate created jointly by students, teachers, and the larger societal context.

The first movement toward autonomy, socialization, refers to learners in the initial phase of joining a group or class, getting to know their fellow group members and feeling comfortable in their group. During this stage it is essential that group membership becomes part of the learners' identity. In $\mathrm{Cl}$, this is known as "positive identity interdependence." Team and class-building activities can be useful here (Kagan, Kagan \& Kagan, 1997; Kagan, Robertson, and Kagan, 1995). For example, during an initial class meeting simply learning one another's names and having the chance to exchange a few words can help create feelings of membership. The key idea at this stage is that all participants feel surrounded by what Palmer (1998) calls the "resources of community."

The second movement toward autonomy, dawning metacognition, refers to learners examining their own learning process. This examination takes place more readily in groups because students can discuss their thoughts, beliefs, and behaviors with each other and can compare their own views with those of their group-mates. Activities to facilitate metacognition include students explaining to each other how they thought of an answer instead of just telling the answer, thinking aloud when working on a task, and disagreeing politely. Another collaborative activity for fostering metacognition is what the CL literature calls "processing group interaction" (Johnson, Johnson \& Holubec, 1993). Here students assess how well they have worked together and how they can improve 
collaboration in the future. This assessment can involve self, peer, and group feedback.

Initiating cboice, the third movement toward autonomy, can occur simultaneously with the first two and involves students making choices about learning such as selecting an activity, choosing how to present their work, and receiving input on how assessment will be conducted. Students can also choose roles to play within their groups. These roles may be concerned with the mechanics of the activity, such as the timekeeper or the recorder, as well as roles more concerned with group functioning such as the encourager, who encourages all members to participate, and the checker, who checks whether everyone understands the activity.

Socialization, metacognition, and initiating choice can be more readily observed when students give feedback on class content and activities: For instance in action logging (Murphey, 1993) students write reflections on their learning process and its context. The quote below, from an L2 student's action log, demonstrates how structures such as collaborative testing (Murphey, 1995) can enhance learning, promote a cooperative spirit among students, and help students feel more confident about their L2 proficiency.

1 enjoyed the test very much. It was not difficult for me because I could prepare for it in advance. So I did it with fun! At first, I had thought that it might be a written one. It was not, but a collaborative test which was new for me. The evaluation of it depends on our subjective judgement. It is a little difficult for me because I have been so familiar with teacher's objective Isicl judgement which is thought to be "fair." Japanese traditional teachers often compare us with other students. We have to compete each other. But in your class, the rival of our study is ourselves. The most important thing is whether we do our best and satisfy ourselves or not. It encourages me a lot because I can be proud of myself. In this class, I tried to do my best, I made a lot of friends and was impressed by them through this class (Nori, 7/99).

Murphey labels the fourth movement expanding autonomy. At this point the students' range of choices grows. They may be involved in self-assessment and in providing feedback to the teacher regarding the most beneficial ways for them to learn. Murphey suggests that the students' expanding autonomy can travel outside the classroom through self-selection of partners and ways to enhance learning on their own with significant co-learners. By this stage the students have socialized into a group, initiated choices, and become aware of their strategies but perhaps not about their beliefs or their identities. They may consciously start near peer role modeling as discussed above. 
The fifth and most advanced movement in this framework is critical collaborative autonomy. By this point learners have come to appreciate how and why "two heads are better than one" and also that through "respectful interdependence" (Murphey, 1998b, p. 28), everyone can benefit from the group. This fifth movement constitutes the focus of the next section.

\section{Critical Collaborative Autonomy}

We have suggested that "autonomy" combines well with "collaborative" because collaboration offers a powerful means of promoting autonomy among 12 learners. Now we would like to explain why adding "critical" to "collaborative autonomy" creates a more useful concept. The rationale consists of two parts. The first concerns the "how" of collaborative autonomy, and the second concerns the "what."

The "how" involves each individual using the analytical powers that Shor (1993) has described for critical literacy (see also, Brown, 1999):

IAlnalytic habits of thinking, reading, writing, speaking, or discussing which go beneath surface impressions, traditional myths, mere opinions, and routine cliches; understanding the social contexts and consequences of any subject matter; discovering the deep meaning of any event, text, technique, process, objects, statement, image, or situation; applying that meaning to your own context (p. 32).

It is also important to find the right mix between working with others and doing one's own thinking. Trim (1997) describes this mix in the context of the Council of Europe's efforts at 1.2 education:

[Learners] recognise the rights of others and accept the necessary constraints on living in a society in a co-operative spirit. For learners, this means linguistic and cultural awareness, study and heuristic skills, and also social skills, an understanding of what is best done alone or in pairs and groups and in the latter case a willingness to engage in democratic decision making (p. 15).

The "critical," defined as the assertive questioning of ways, means, and outcomes, acts against overly acquiescent collaboration. Students may need activities and examples that show that dissent is not counter to collaboration but is essential to the effectiveness of groups. Courageous examples of dissent, such as M. Gandhi, Nelson Mandela, and Aung San Suu Kyi, show on an international level what is also true in a small group: the virtue of standing up for one's views even in the face of great pressure to desist. This is in contrast to sheepishly collaborating to keep things smooth on the surface. In critical collaborative autonomy, "yes-people" and "sheep" are as unhealthy as the "rugged individualist 
loner" and the "egocentric narcissist." Mandela put this nicely describing Gandhi: "He replaced self-interest with group interest without minimizing the importance of self. In fact, the interdependence of the social and personal is at the heart of his philosophy" (1999, p. 75).

Pennycook (1997) advocates the same critical perspective in pursuit of discovering student voices:

Autonomy ..... is not something achieved by the handing over of power or by rational reflection; rather, it is the struggle to become the author of one's own world, to be able to create one's own meanings, to pursue cultural alternatives amid the cultural politics of everyday life (p. 39).

The second reason why "critical" belongs with "collaborative autonomy" in L2 education concerns the "what" of the term, that is, what students autonomously collaborate about. Benson (1997) disapproves of reductive approaches to autonomy that deal solely with technical aspects without realizing that the concept is a social one as well, a concept with impact on how people view the world around them and on how they act. In systems theory (Kauffman, 1980), it is acknowledged that one part of a system cannot change without changes occurring in other parts of the system. As teachers of autonomy we have to be open to the fact that, in developing autonomy, learners will develop their own approach to learning. This can at times lead to Freirian social activism (Freire, 1970). In the same way, cooperation can be seen as not only a good way to learn; it can also be recommended as a good way to live and to view the world. For instance, some scholars in the area of CL (e.g., Sapon-Shevin, 1999) advocate that cooperation be taught as a value. Further, groups can serve as a forum to help students critically analyze their world, and, based on their analysis, then use the power of their group to speak and act powerfully. As Kohn (1993, p. 9) states, "Students should not only be trained to live in a democracy when they grow up; they should have the chance to live in one today." In this way, via their academic education, students can learn to value and enact the skills and attitudes necessary to be active citizens who exercise their rights and responsibilities in a society where cooperation is prized over competition. Thus, autonomy, cooperation, and related topics become classroom themes as well as classroom methods.

Thus what starts as a way of giving students more control over their learning, through critical collaborative autonomy becomes a more expansive educational ideology which can engender sociocultural and political changes (see Santos, 1992 for an analysis of how the critical and ideological are treated in different domains). Our personal stance is that, while we do not start out with social activism as the "how" or 
"what" of our teaching, we recognize its eventual potential and welcome it as a balancing and developmentally healthy extension of living critically in the world. Some readers may feel that this may sound like cultural imposition; however we believe such a view of critical collaborative autonomy promotes development for students and educators everywhere.

\section{Conclusion}

In this article, we have discussed the paradigm shift towards learnercenteredness, the foundation of pedagogy to promote learners' autonomy. We have considered how students can benefit from collaborating, how ideas from cooperative learning can enhance that collaboration, why collaboration and learner autonomy make a good match, how teachers can facilitate autonomy, and why a critical component complements collaboration and autonomy.

We offer the term "critical collaborative autonomy" because we believe the concepts embodied within it will have a generative effect, inspiring us to realize its potential. Since "participation precedes learning" (Bateson, 1994, p. 41) we have looked at how we might engage students incrementally in ever more intensive participation with others to critically examine and improve themselves and their learning communities. We believe that this participation is on a developmental trajectory toward critical collaborative autonomy.

Teachers can support this by doing exploratory teaching and action research to find ways to support critical collaborative autonomy. A look into most classrooms, even after the 20 th century changes we mentioned earlier, reveals that many students still are not participating in shaping their own education. Although educational systems in both the west and the east need to promote collaborative autonomy, critical approaches are often met with resistance instead of being welcomed. However, we believe that through increasing students' autonomy within a community of learners, everyone will be enriched through synergistic and critical collaboration, thus continuing the progress witnessed in the past century. L2 educators can be a factor in that progress.

\section{Acknowledgements}

We are grateful to Thomas Farrell for feedback on an earlier draft and to two anonymous reviewers who were constructively critical and collaborative. Murphey's research has been supported by annual Pache I-A grants from Nanzan University since 1995. 
Tim Murpbey is a professor at Nanzan University until March 2001. He has voluntarily resigned from his tenured position after 11 years over a difference of values concerning the running of the entrance exams. He is currently investigating sociocultural theory applied to educational change. E-mail: <mits(icicnanzanu.ac.jp>. Website: http://www.ic.nanzan-u.ac.jp/ mits/.

George M. Jacobs is a language specialist at the Southeast Asia Ministers of Education Organization (SEAMEO) Regional Language Centre (REIC) in Singapore. His main academic interests are cooperative learning and environmental education. E-mail: <gmjacobs@pacific.net.sg>. Website: http://www.geocities.com/ Athens/Thebes/1650/index,htm

\section{References}

Areglado, R. J. Bradley, R. C., \& Lane, P. S. (1996), Learning for life: Creating classrooms for self-directed learning. Thousand Oaks, CA: Corwin Press.

Aronson, E., Blaney, N., Stephan, C., Sikes, J., \& Snapp, M. (1978). The jigsau: classroom. Beverley Hills, CA: Sage

Assinder, W. (1991). Peer teaching, peer learning: One model. ELTJournal, 45, 218-229.

Bandura, A. (1977). Social learning theory. Englewood Cliffs, NJ: Prentice Hall.

Bandura, A. (1986). Soctal foundations of thought and action: A social-cognitive theory. Englewood Cliffs, NJ: Prentice Hall.

Bateson, M.C. (1994). Peripheral visions. New York: Harper Collins.

Bejarano, Y., Levine, T, Olshtain, E., \& Steiner, J (1997). The skilled use of interaction strategies: Creating a framework for improved small-group communicative interaction in the language classroom. System, 25, 203-214.

Benson, P. (1997). Concepts of autonomy in language learning. In R. Pemberton, E.S.L. Li, W.W.F. Or, \& H. D. Pierson (Eds.), Taking control: Autonomy in language learning (pp. 27-34). Hong Kong: Hong Kong Liniversity Press.

Bereiter, C., \& Scardamalia, M. (1987). The psychology of written composition. Hillsdale, NJ: Erlbaum.

Bossert, S.T. (1988-1989). Cooperative activities in the classroom. Review of Research in Education, 15, 225-252.

Breen, M., \& Mann, S. (1997). Shooting arrows at the sun: Perspectives on a pedagogy for autonomy, In P. Benson \& P Voller (Eds), Autonomy and independence in language learning, (pp. 132-149). London: Longman.

Brown, H. D. (1994). Teaching by principles. An interactive approach to language pedagogy. Englewood Cliffs, NJ: Prentice Hall Regents.

Brown, J. S., Collins, A., \& Duguid, P. (1990). Situation cognition and the culture of learning. Educational Researcber, 18, 32-42.

Brown, K. (1999). Developing critical literacy. Sydney: National Centre for English Language Teaching and Research.

Bruner, J. (1966). Toward a theory of instruction. New York: Norton.

Coelho, E. (1992). Cooperative learning: Foundation for a communicative curriculum. In C. Kessler (Ed.), Cooperative language learning (pp. 31-50) Englewoòd Cliffs, NJ: Prentice Hall Regents. 
Cohen, E.G. (1994). Restructuring the classroom: Conditions for productive small groups. Review of Educational Research, 64, 1-35.

Collis, B., \& Heeren, E. (1993, August/September). Tele-collaboration and groupware. The Computing Teacher, 36-38.

Dam, L. (1995), Learner autonomy 3: From theory to classroom practice: Dublin: Authentik.

Dickinson, L. (1999, June 4). Questions 9 and 10: Part 2 of 2 parts. Autonomy List. AUTO-L@ycyax.york, cuny, edu.

Donato, R. (1994). Collective scaffolding in second language learning. In J. P. Lantolf \& G. Appel (Eds.), Vygotskian approaches to second language research (pp, 33-56). Norwood, NJ: Ablex.

Freire, P. (1970). Pedagogy of the oppressed. New York: Continuum.

Geary, W.T. (1998, April). From dependence toward independence via interdependence. Paper presented at the annual meeting of the American Educational Research Association, San Diego.

Harmer, J. (1998). How to teach English. Harlow, Essex: Addison Wesley Longman. Harris, V., \& Noyau, G. (1990). Collaborative learning Taking the first steps. In I. Gathercole (Ed), Autonomy in language learning (pp. 55-64). London: Centre for Information on Language Teaching.

Hartup, W. W. (1992). Having friends, making friends, and keeping friends: Relationships as educational contexts. (ERIC Document Reproduction Service No. ED 345854 ).

Higgs, J. (1988). Planning learning experiences to promote autonomous learning. In D. Baud (Ed), Developing student autonomy in learning ( 2 nd ed.) (pp. 40-58). London: Kogan Page.

Hilt, P. (1992). The world-of-work connection. In N. Davidson \& T. Worsham (Eds.), Enbancing tbinking througb cooperative learning (pp. 251-265). New York: Teachers College Press.

Johnson, D.W., \& Johnson, R.T. (1989). Cooperation and competition: Theory and research. Edina, MN: Interaction Book Company.

Johnson, D.W., \& Johnson, R.T. (1994). Learning together and alone (4th ed.). Boston: Allyn and Bacon.

Johnson, D.W Johnson, R.T., \& Holubec, E.J. (1993). Circles of learning (4th ed.). Edina, MN: Interaction Book Company.

Kagan, L, Kagan, M., \& Kagan, S. (1997). Cooperative learning structures for team building. San Clemente, CA: Kagan Cooperative Learning.

Kagan, M., Robertson, L., \& Kagan, S. (1995). Cooperative learning structures for class building. San Clemente, CA: Kagan Cooperative Learning.

Kauffman, D (1980). Systems 1: An introduction to systems tbinking. Minneapolis: Carlton

Kenny, B, (1993). For more autonomy, System, 21, 431-442.

Kohn, A. (1992). No contest: The case against competition ( 2 nd ed.). Boston: Houghton Miflin.

Kohn, A. (1993). Choices for children-Why and how to let students decide. Pbi Delta Kappan, 75 (1), 8-19.

Lee, I. (1998). Supporting greater autonomy in language learning ELT Journal, 
$52,282-290$

Liang, X., Mohan, B.A., \& Early, M. (1998). Issues of cooperative learning in ESI classes: A literature review. TESL Canada Journal, 15 (2), 13-23.

Littlewood, W. (1996). "Autonomy": An anatomy and a framework. System, 24, 427-435.

Lockhart, C., \& Ng, P, (1995). Analyzing talk in ESL peer response groups: Stances, functions, and content. Language Learming, 45, 605-655.

Macaro, E. (1997). Target language, collaborative learning and autonomy. Clevedon, Avon: Multilingual Matters.

Mandela, N. (1999, December 27). The sacred warrior. Time, 154 (26), 75-76.

Murphey, T. (1993). Why don't teachers learn what learners learn? Taking the guesswork out with Action Logging. English Teaching Forum. Washington, DC: USIS, 6-10,

Murphey, T. (1995). Tests: Learning through negotiated interaction. TESOL Journal, 4 (2), 12-16.

Murphey, T. (1998a). Motivating with near peer role models. In B. Visgatis (Ed.), On JALT97: Trends \& Transitions (pp. 205-209). Tokyo: JALT.

Murphey, T. (1998b). Stages of facilitation: Conceptualizing learner development. Nanzan LT Briefs, 8, 26-27.

Nelson, G. L. (1995). Peer response groups. In R. V. White (Ed.), New ways in teaching writing (pp. 128-130). Alexandria, VA: TESOL.

Nunan, D. (1997). Towards autonomous learning: Some theoretical, empirical and practical issues. In R. Pemberton, E.S.L. Li, W.W.F. Or, \& H.D. Pierson (Eds.), Taking control: Autonomy in language learning (pp. 14-26). Hong Kong: Hong Kong University Press.

Palmer, PJ. (1998). The courage to teach: Exploring the inner landscape of a teacher's life. San Francisco: Jossey-Bass.

Pemberton, R. (1996). Introduction. In R. Pemberton, E.S.L. Li, W.W.F, Or, \& H. D. Pierson (Eds.), Taking control: Autonomy in language learning (pp. 1-8) Hong Kong: Hong Kong University Press.

Pennycook, A. (1997). Cultural alternatives and autonomy. In P. Benson \& P. Voller (Eds.), Autonomy and independence in language learning (pp. 35-53). New York: Longman.

Pickard, N. (1996). Out-of-class language learning strategies. ELT Journal, 50, 150-159.

Pierson, H.D. (1996). Learner culture and learner autonomy in the Hong Kong Chinese context. In R. Pemberton, E.S.L. Li, W.W.F. Or, \& H.D. Pierson (Eds.), Taking control: Autonomy in language learning (pp, 49-58). Hong Kong Hong Kong University Press.

Reid, J. M. (1993). Teaching ESL writing. Englewood Cliffs, NJ: Prentice Hall. Santos, T, (1992), Ideology in composition: L1 and ESL. Journal of Second Language Writing, 1,1-16.

Sapon-Shevin, M. (1999). Because we can change the world: A practical guide to butlding cooperative, inclusive classroom communities. Boston: Allyn and Bacon.

Sharan, S. (1980), Cooperative learning in small groups: Recent methods and 
effects on achievement, attitudes and ethnic relations. Review of Educational Research, 50, 241-271.

Shor, I. (1993). Education is politics: Paulo Freire's critical pedagogy. In P. McClaren \& P. Leonard (Eds.), Paulo Freire: A critical encounter (pp. 25-35), London; Routledge.

Slavin, R. E. (1995). Cooperative learning: Theory, research, and practice (2nd ed.). Boston: Allyn and Bacon.

Stanley, J. (1992). Coaching student writers to be effective peer evaluators. Journal of Second Language Writing, 1, 217-234.

Trim, J. (1997), Learner autonomy and the Council of Europe. LATEFL Newsletter, $139,14-16$.

Van Lier, L. (1996). Interaction in the language curriculum: Awareness, autonomy \& authenticity. London: Longman.

Vygotsky, L.S. (1978). Mind in society: The development of higher psychological processes (M. Coles, V. John-Steiner, S. Scribner, \& E. Souberman, Trans.). Cambridge, MA: Harvard University Preśs.

Wells, G, (1999), Dialogic inquiry: Towards a sociocultural practice and theory of education. Cambridge and New York: Cambridge University Press.

(Received January 28, 2000; revised May 11, 2000)

\section{Appendix 1 - List of Cooperative Learning Websites and Listservs}

1. Gan Siowck Lee's Home Page for Educators. Lee has compiled lots of good resources on $\mathrm{CL}$, including some of her own work. http://pppl.upm.edu.my/ $\sim \mathrm{gansl} / \mathrm{cl} \cdot \mathrm{html}$

2. International Association for the Study of Cooperation in Education (LASCE). links to a site with lots of papers on CL and computers. http:// miavx1.acs.muohio.edu/ iascecwis/

3. Perspectives on Hands-On Science Teaching by David L. Haury and Peter Rillero, http://www ncrel org/skrs/areas/issues/content/cntareas/science/eric/ eric-toc htm

4. Richard Felder's Homepage. Felder teaches engineering at North Carolina State (USA) University. Lots of good stuff here related to CL. http:// www2.ncsu.edu/unity/lockers/users/f/felder/public/RMF/html

5. Theory and Practice by University of Athabasca, Canada. http://ccism.pc.athabascau,ca/html/ccism/deresrce/theory.htm

6. Center for Social Organization of Schools at the Johns Hopkins University. For more than 25 years the Center has conducted programmatic research to improve the education system, as well as developing curricula and providing technical assistance to help schools use the Center's research. The site includes information 
on the Center for Research on the Education of Students Placed at Risk (CRESPAR) as well as Success For All and Roots \& Wings. http://scov.csos.jhu.edu/

7. Cooperative Learning Center at the University of Minnesota (USA). Co-Directors: Roger T. Johnson and Dayid W. Johnson. http://www.clcrc.com/

8. Active and Cooperative Learning by Bridget M. Smyser. http://www.wpi.edu/ isg_501/bridget.html

9. I is for Interaction - Not Isolation. Words on Cooperative Learning and Technology http://137.48.46.72/htmldocs/techcoop.html

10. Cooperative/Collaborative Learning by Susan Ledlow and Neil Davidson. http://www2.emc.maricopa.edu/innovation/CCL/CCL.html

11. Kagan Cooperative Learning. This site offers a newsletter, a Q\&A section, workshop information, and the chance to buy $\mathrm{CL}$ and related material, e.g., Multiple Intelligences. http://www.kagancooplearn.com/

12. The Cooperative Learning Network, This is an association of colleagues at Sheridan College, Ontario, Canada, who model, share, support, and advocate the use of cooperative learning. It includes the TiCkLe (Technology in Cooperative Learning) Guide. http://www sheridanc on_ca/coop_learn/cooplrn, htm

13. Computer Supported Collaborative Learning. This site contains papers from a 1995 conference, http://www-cscl95 indiana edu/cscl95/toc.html

14. Ted Panitz's Homepage. Panitz teaches mathematics at Cape Cod (USA) Community College. His page includes two E-books, one on CL and one on Writing across the Curriculum. Also included are some of the wide-ranging internet discussions that he has put together across several Lists. hitp:// www.capecod.net/ ipanitz/tedspage

15. Pete Jones' Home Page. Jones is Head of Modern Languages at Pine Ridge Secondary School in Ontario, Canada, and presents cooperative learning strategies that he and others have developed. http//www.geocities.com/Paris/LeftBank/ $3852 /$ index $h t \mathrm{ml}$

16. Centre for the Study of Learning and Performance is a research center at Concordia University, Canada. Their goal is to study and promote effective teaching/learning strategies through active association with schools, administrators, and teachers, particularly in the areas of cooperative learning and integrated technology. See the resources page: http://doe.concordia.ca/ cslp

17. ERIC Abstracts on Cooperative Learning presents selected abstracts on cooperative learning prepared by the Association on Supervision and Curriculum Development (ASCD). http://www ascd org/services/eric/ericcoo.html

18. Mid-Atlantic Association for Cooperation in Education (MAACIE). The site includes articles from MAACIE's Newsletter. http://www.geocities.com/ maacie/ 
19. Program for Complex Instruction, Stanford University (USA). This site features the work of Elizabeth Cohen, Rachel Lotan, and their colleagues focusing on the sociology of groups, in particular the treatment of status differences among group members. http://www.stanford.edu/group/pci/

20. Rikki Ashley's Cooperative Learning Homepage. Basic information on CL plus an assortment of activities. http://members.home.net/riketa/index.htm

21. George M. Jacobs' website. Go to the CL section for articles on CL. http $/ /$ www.geocities.com/Athens/Thebes/1650/index.htm

22. Cooperative Learning Listserve. Those interested in an international LISTSERV on $\mathrm{CL}$ may by sending an e-mail message to: <majordomo@jaring.my>. Include in the body of the message: SUBSCRIBE CL. All postings to the list should be sent to: <CL@iaring my>. 